\title{
DEVELOPING KOPAJA.ID AS A FUN ONLINE LEARNING IN GENERAL TAX CONDITIONS TOPIC
}

\author{
Rumiyati $^{1 *}$, Dianila Oktyawati ${ }^{1}$ \\ ${ }^{1}$ Universitas Gadjah Mada \\ J1. Persatuan, Blimbing Sari, Caturtunggal, Depok, Sleman, Yogyakarta 55281, Indonesia
}

\begin{abstract}
Kopaja.id as online learning had developed in 2019, and KOPAJA is an acronym for "Kompas Pajak Ajaib" which means magically direct taxes. It is also expected to provide a fun learning for students. This research is to provide an online fun learning to students who want to learn tax anytime and anywhere. This research is follow-up research using the research and development $(R \& D)$ method to reach the Technology Readiness Level (TRL) for applied research. The development of an application system has been carried out based on a website with the address https://kopaja.id which can be accessed and used for learning from taxation courses. User testing with the Perceived Usability Website instrument was developed by Wang and Senecal. The research sample is from 55 students of DIV Public Sector Accounting, Department of Economics and Business, Vocational College, Universitas Gadjah Mada. The test results show that the website system is functioning correctly, and user ratings show that the website has easy navigation, speed of access, and is comfortable to explore. However, interaction with users is still not optimal. The result of self-measurement on the achievement of Technology Readiness Level reaches TRL 6 in 19 scale.
\end{abstract}

Keywords: online learning, kopaja, general tax conditions, taxation

How to cite: Rumiyati, R., \& Oktyawati, D. (2020). Developing Kopaja.id as a fun online learning in general tax conditions topic. Jurnal Pendidikan Vokasi, 10(3), 282-289. doi:https://doi.org/10.21831/jpv.v10i3.36023

*Corresponding Author: Rumiyati rumi_yati@ugm.ac.id

Department of Public Sector Accounting, Vocational College, Universitas Gadjah Mada

Jl. Persatuan, Blimbing Sari, Caturtunggal, Depok, Sleman, Yogyakarta 55281, Indonesia 


\section{INTRODUCTION}

Literacy is an individual's ability to process information and knowledge for life skills (Kamus Besar Bahasa Indonesia, 2016). The digital era is full of information via the internet; a student is required to be a proactive learner and a lecturer who also provides active and effective teaching. Literacy between students and lecturers must be built together in synergy in the process of teaching and learning activities in class. This is influenced by the role of computer technology and information that has developed rapidly so that the term digital literacy becomes a necessity that will happen. Digital literacy means the ability to understand and use digital information (Gilster, 1997). Bawden (2001) states that fluency in digital literacy is reflected in the ability to read and write using online sources and the ability to select relevant sources for assignments, synthesizing information into coherent messages that can be conveyed to others.

Online learning will generate digital literacy for students and lecturers in universities. Research on online learning has been conducted by Kuntarto (2017) for the Indonesian language subject in the undergraduate program. Online learning models can increase student absorption of the course material, with an increase of more than $81 \%$ compared to using only face-to-face learning models. Online learning has provided new experiences that are more challenging than conventional learning models. Therefore, online learning can also be used for other subjects such as Taxation. The Ministry of Research, Technology and Higher Education has developed SPADA which stands for Sistem Pembelajaran Daring in Indonesia, or an Indonesian Online Learning System, one of which is online learning to include (inclusion) tax awareness in subjects at school and courses on campus (Direktorat Jenderal Pembelajaran dan Kemahasiswaan Kementerian Riset, Teknologi, dan Pendidikan Tinggi, 2019). Meanwhile, Aghni (2020) has presented an online learning module on tax administration for teacher education programs in positions in deepening the field of accounting and finance studies.

The online module consists of digital material modules, instructional videos, presentation media, and other reading sources, and ends with a formative and summative test. The online learning module is useful for improving the quality of teachers in teaching students. In 2019, Kopaja.id online learning has been developed with the address https://kopaja.id which is complementary to the simulation props for the types and tax rates of KOPAJA which have received a Copyright certificate from the Ministry of Law and Human Rights of the Republic of Indonesia with recording number 000153144 dated 6 August 2019. KOPAJA is an acronym for Kompas Pajak Ajaib which means magical taxes compass; online learning kopaja.id is also expected to provide magical and fun directions. Innovations have been made in the development of kopaja.id version 1 by providing online practice questions and obtaining direct value information. However, there are still some obstacles, including kopaja.id which is still static, there is no admin panel so it cannot be updated, and the material is limited to central taxes and local taxes. The kopaja.id version 1 page is still static and does not have an admin panel as evidenced by the material components on the page that are only limited to material uploaded by the system developer.

Previously, a self-assessment had been carried out for the level of technology readiness still at Technology Readiness Level (TRL) 2, namely at the technology application level. Therefore, it is necessary to carry out further research for the development of kopaja.id as a means of online learning on the topic of general tax provisions with a fun concept with the goal of reaching TRL 6 in 1-9 scale. The development of kopaja.id version 2 will use instructional systems from Dick et al. (2009) so that online learning outcomes on general tax provisions can be achieved effectively. How to compile an effective online learning concept on the topic of general tax provisions through online media kopaja.id? How to build a kopaja.id prototype version 2 so that learning online about general tax provisions becomes fun? This research is expected to be able to make kopaja.id reach TRL level 5 and can be used for accounting vocational students in learning general tax provisions in a more enjoyable manner accompanied by online question practice. Providing an alternative to effective online learning media with the Dick and Carey instructional design system (D'Angelo et al., 2018) and testing user acceptance through instruments developed by Wang and Senecal (2007).

The term fun online learning, as elaborated in Kamus Besar Bahasa Indonesia (2016), is started with learning, which is a process, way, and act of making learning, whereas online means 
being in a network, connected via computer networks, the internet, and so on. From the meaning of this term, it can be interpreted that online learning is a learning process using an internet network through the media of computers, sophisticated cellphones, and so on. Thorne (2003) explains that online learning is learning that uses multimedia technology, virtual classes, video, voice messages, e-mail and conference calls, animated online text, and online video streaming. Cox (2019) reveals that there are ten ways to make learning fun by (1) creating simple scientific experiments: simple scientific experiments before introducing new concepts using graphs can allow students to predict what will happen during the experiment; (2) allowing students to work together; (3) using hands-on activity involves students in digging up information by asking questions, doing activities and finding, collecting data and analyzing and making conclusions on a material/concept; (4) giving students to do brain rest: giving students pause to do learning activities will make learning more successful; (5) inviting students to take field trips: teachers are teaching students by inviting students to a certain place or object outside of school to learn things that are obtained in class and see the outside world. Students can relate the concept to everything seen during the field trip; (6) making review time enjoyable: students are often in a state of depression when they hear the word review, so it is necessary to create a pleasant review; (7) incorporating technology into classroom materials: technology can make learning fun; (8) creating fun learning: learning centre can give students the ability to work together, and learn together; (9) teaching according to students' abilities: each student has a different type of intensity, so it is necessary to teach with attention to students' abilities; (10) limiting rules in class: many rules and expectations can hinder the learning process.

Kamus Besar Bahasa Indonesia (2016) defines that fun is making fun; rejoice; arouses pleasure; satisfying; captivate; feeling happy (satisfied and so on) about; like. From the various explanations of the previous literature, it can be concluded that fun online learning can be defined as the process, method, and action for learning that arouses pleasure through multimedia/computers/internet networks.

D'Angelo et al. (2018) explain that the Dick and Carey instructional system consists of nine stages elaborated as follows. (1) Identification of instructional goals setting: The expected objectives of instruction after studying the material with needs analysis by knowing the experience of students as learners when they experience difficulties when learning, analyzing people who are working in the scope of content being developed, and other parties related to the objectives of learning instruction. (2) Carrying out an instructional analysis: This instructional analysis is associated with the definition of learning outcomes from the definition of Bloom et al. (1956) with cognitive, psychomotor, and affective/behaviour components, knowledge, comprehension, application, analysis, synthesis, and evaluation. (3) Learner analysis and context: Analysis of learner targets and learning contexts will be carried out by taking into account previous skills, prior knowledge of a topic, behaviour towards the context and mode of delivery, academic motivation, educational levels and abilities, learning preferences, and group characteristics. (4) Writing performance achievement goals: Performance outcomes should include three parts as follows: (a) condition, which means a description of the capabilities that have been identified with the tools and resources needed to achieve the capability, (b) behaviour, which means a description of expertise including action, content, or concept, and (c) criteria, which mean an acceptable description of performance. (5) Development of assessment instruments: After the performance achievements have been determined, then developing an assessment instrument from each individual. The main emphasis is on the types of abilities described with the goals that have been set. (6) Development of an instructional strategy: Instructional strategies are a variety of teaching and learning strategies which can take the form of group discussions, independent reading, practicum, and others. Strategy development needs to consider the goals, motivation and characteristics of learners, learning objectives, assessment requirements, and performance context. (7) Development and selection of instructional materials: The materials contain material, for example, student workbooks, activity guides, problem scenarios, reference lists, or computer simulations. When in this stage, instructional materials should still refer to the performance achievement stage and the assessment instrument. (8) Designing and carrying out a formative evaluation: Dick et al. (2005) define formative evaluation as the acquisition of data and information while providing instructions that can be used to review the effectiveness of instructions. Examples of formative evaluation can be in the form of questionnaires, student obser- 
vations, note analysis, interviews, self-assessments, short quizzes, and discussions. (9) Designing and carrying out summative evaluations: Dick et al. (2005) define summative evaluation is the collection of data and information while providing instructions that can be used to review the overall effectiveness of instructions. Summative evaluation measures several performance achievements. The difference between formative and summative evaluation is that formative evaluation can identify improvements needed during the process of learning. In contrast, summative evaluation places more emphasis on identifying strengths and improvements after the learning process ends.

General tax conditions are contained in Law no. 6 of 1983 which has been amended by Law of the Republic Indonesia No. 28 of 2007 and Law of the Republic of Indonesia No. 16 of 2009. The general tax conditions in Indonesia explain information regarding to the meaning of tax, tax review from various aspects, tax functions, tax collection principles, taxpayer identification number, company's taxes, tax obligations, tax revocation. In addition, the general tax conditions are also study definition, function, place of payment and deposit, the deadline for payment or deposit, tax notification letter both the definition, function, settlement procedure, correction, type, the deadline for submission, the extension of a time period. Besides that, general tax topic includes tax reporting, sanctions for being late and not submitting tax report, tax assessment letters, tax bills, coercive letters, examinations, investigations, coercive letters, objections, appeals, reconsiderations, confiscation and auction, and prevention and hostage-taking (Law of the Republic of Indonesia No. 28 of 2007; Law of the Republic of Indonesia No. 16 of 2009).

\section{RESEARCH METHOD}

The research method uses research and development (Research and Development). This method is a method used to produce products from the process of problem identification, data collection, product design, product manufacturing, and product testing (Sugiyono, 2015). The research design uses a waterfall approach as presented in Figure 1.

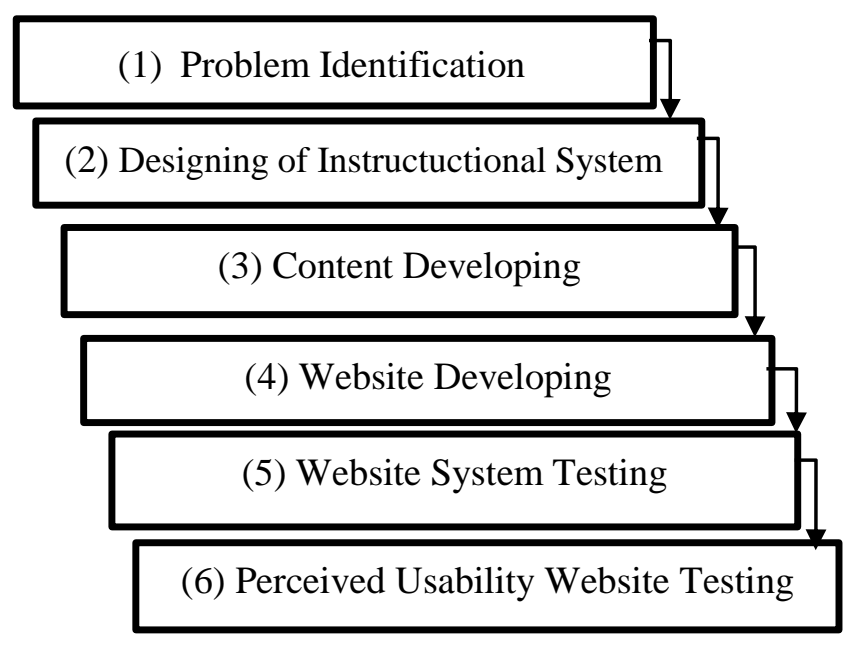

Figure 1. Waterfall Approach

Stage 1 is identifying problems on the kopaja.id version 1 , which has been developed in 2019. The second stage is designing an instructional system referring to the Dick and Carey system (D'Angelo et al., 2018). The third and fourth stages are preparing the content of the General Tax Conditions, and designing version 2 of the kopaja.id by fixing the problems in kopaja.id version 1 . The fifth stage is testing the page, whether there is a system malfunction of each menu in kopaja.id. The last stage is testing the user acceptance using an instrument developed by Wang and Senecal (2007). The questionnaire instrument will also be tested using validity and reliability. Testing the questionnaire instrument must meet the validity and reliability test. Testing was carried out with SPPS version 21 . Testing the validity using the Pearson correlation, reliability testing was done by looking at the Cronbach's Alpha value. 


\section{RESULTS AND DISCUSSION}

The first stage of problem analysis on the kopaja.id learning website version 1 shows that the website is still static, and there are limited learning materials on central taxes and local taxes. The Indonesian Institute of Accountants - the Compartment of Educator Accountants or Ikatan Akuntan Indonesia Kompartemen Akuntan Pendidik (IAI KAPd) (2015) has compiled a national standard of education for accounting vocational education, one of the achievements of the Diploma IV Public Sector Accounting learning in the aspect of special knowledge: "14. Mastering theoretical concepts in depth on tax regulations relevant to individual and corporate taxpayers".

Therefore, kopaja.id version 2 creates an admin panel so that it can be done updating the material and adding menus according to the needs of users of Accounting vocational students. In order to fulfill the learning achievements of special knowledge for Diploma IV (DIV) Public Sector Accounting students, it is necessary to make general conditions on taxation as material for students to master theoretical concepts in depth on tax regulations relevant to individual and corporate taxpayers.

The second stage is the design of the Dick and Carey instructional system, with nine stages as follows. (1) Identification of instructional goals: Determination of expected instruction objectives after performing an identification a need analysis by conducting interviews with two taxation lecturers of the Department of Economics and Business, Vocational Collage, Universitas Gadjah Mada (UGM), Yogyakarta, Indonesia, who have tax consultant certification. The interview material was focused on general tax conditions and conducted at August 17, 2020, through online/virtual interview. Recommendations from the two experts were divided into 13 materials, namely: tax concepts, taxpayer identity number, taxable entrepreneurs, tax payments, tax assessments, tax returns, invoices, accounting and tax audits, tax investigations, compulsory letters, objection, appeal and review, confiscation and auction, and prevention and taking of hostages. (2) Carrying out an instructional analysis: Analysis of instructional material by looking at the learning outcomes of DIV Public Sector Accounting graduates based on national education standards for accounting vocational education that have been compiled by Ikatan Akuntan Indonesia Kompartemen Akuntan Pendidik (2015). (3) Learner analysis and context: The target of learners is public sector accounting vocational students so that the context developed is in accordance with the taxation course syllabus. (4) Writing performance achievement goals: The writing of written learning performance achievements in each material designed will be uploaded in the General Tax Conditions menu at kopaja.id version 2 with an address that can be accessed anywhere and anytime at https://kopaja.id. (5) Development of assessment instruments: The assessment instrument uses the tax question exercise menu according to the material being developed. The assessment instruments are divided into two types; that can be accessed by a regular and premium user. (6) Development of an instructional strategy: Kopaja.id users can do an ability test with a menu of practice questions and quizzes in real-time so that it attracts users' attention to learn. The value of the practice questions is displayed live. (7) Development and selection of instructional materials: The thirteen general tax conditions are adjusted to the learning outcomes, and the material is taken from tax regulations in force in Indonesia and tax books. (8) Designing and carrying out a formative evaluation: It is carried out by providing practice questions for each material and accompanied by discussion so that students as users can find out the right and wrong answers. (9) Designing and carrying out summative evaluations: Its evaluation is carried out by providing a quiz menu specifically for premium users with easy, medium, and difficult quiz categories.

The third stage is the preparation of content or material to be uploaded, both in the form of taxation material, as well as tax questions and discussions. Quiz questions for summative evaluation consist of three types of easy questions, medium questions, and difficult questions. Sudjana (2017) explains that the proportion of problem difficulty levels can use the 3-4-3 model, which means that there are $30 \%$ easy items, $40 \%$ medium items, and $30 \%$ difficult items. The fourth stage is that the development of the page is divided into two, namely the first is the creation of an admin panel which functions to facilitate administrators of the kopaja.id page to manage and update taxation materials, questions, and quizzes. The system is equipped with the management of sample questions, practise questions with their discussion and tax quizzes. The system will also be useful 
for optimizing data collection and data capture that can be used as material for evaluating the future development of kopaja.id. The second is the development of the kopaja.id page for user activity from the side of regular members and premium members of kopaja.id. The main difference between regular member users and premium members lies in the tax quiz, which can only be accessed by premium member users. The fifth stage is testing the page in terms of the admin panel system and interface.

Based on system testing for both the admin panel system and the interface that the system can run according to its function. The sixth stage is user testing with the Perceived Usability Website instrument developed by Wang and Senecal (2007). This instrument was developed to determine the extent to which users of the online tax learning page through https://kopaja.id can easily access the page and can interact easily and effectively. There are 15 questions with three dimensions (navigation, speed, interaction, and behaviour) with 7 Likert scales. The sample of user research is from 55 students of DIV Public Sector Accounting, semester three and above, Department of Economics and Business, UGM Vocational School. The choice of third-semester DIV students and above is because these students have already received taxation courses. Testing was carried out on October 27, 2020, using online.

Table 1. Respondent Participation Rate

\begin{tabular}{lc}
\hline \multicolumn{1}{c}{ Respondent Participation } & Rate (\%) \\
\hline Number of Public Sector Accounting DIV Students Class of 2019 and 2020 & 72 \\
Students Who Filled the Questionnaire & 55 \\
Respondent Participation Rate & $\mathbf{7 6}$ \\
\hline
\end{tabular}

Table 1 shows that the response from the respondents was very good with a research participation rate of 55 students (76\% of the study sample. Based on the demographic data of respondents, it is shown that the age of the respondent is at least 18 years old, and at most 25 years old, and the average age is 20 years. Meanwhile, the average GPA of Public Sector Accounting DIV students for semester 3 and above is 3.6 from a scale of 4.0. This shows that students have high academic abilities. User testing refers to the Perceived Usability Website instrument developed by Wang and Senecal (2007) as presented in Table 2.

Table 2. User Testing Instruments

\begin{tabular}{cl}
\hline Dimensions & \multicolumn{1}{c}{ Question Items } \\
\hline Navigation (N) & \\
N1 & I am very easy to complete the tasks I want to complete on the Kopaja.id website. \\
N2 & I find the Kopaja.id website easy to use \\
N3 & I find it very easy to find the information I want on the Kopaja.id website menu. \\
N4 & I find it easy to learn how to use the Kopaja.id website \\
Speed (S) & The speed of information provided by the website is fast enough \\
S1 & Information can be displayed quite quickly \\
S2 & The Kopaja.id website can be accessed quickly \\
S3 & The material pages on the Kopaja.id website can be downloaded quickly \\
S4 & The Kopaja.id website provides customization facilities \\
Interaction (I) & The Kopaja.id website makes me a unique person and can respond to my specific needs \\
I2 & The Kopaja.id website provides content / menus that can be changed individually \\
I3 & The Kopaja.id website provides adequate feedback to assess the progress of my \\
I4 & assignments (practice questions and quizzes) at Kopaja.id \\
Attitude (A) & The Kopaja.id website makes it easy for me to establish a relationship with the Public \\
A1 & Sector Accounting DIV Study Program, DEB, Vocational School, UGM \\
A2 & I am satisfied with the services provided by Kopaja.id \\
A3 & I feel comfortable when exploring the Kopaja.id website
\end{tabular}


Testing the questionnaire instrument must meet the validity and reliability test. The test was carried out with SPPS version 21 . The following are the results of the validity and reliability testing. Validity testing using the pearson correlation shows that 15 questions from the four dimensions of navigation (N1-N4), speed (S1-S4), interaction dimensions (I1-I4), and behavioral (A1A3) are valid because the significance value $<0.05$. Cronbach's Alpha value is 0.9330 so it can be concluded that the instrument is reliable.

Respondents' Assessment of the perceived usefulness of the Kopaja.id resulted easy navigation ability to complete assignments (74.2\% of students agree with average scale 6.32 if navigation in Kopaja.id is easy), speed of information speed $84.4 \%$ of students agree 6.19 with average scale agree if kopaja.id can be accessed quickly), interaction and customization facilities $77.6 \%$ of students with average scale agree. 5.52. Behavioral organizational institutional relationships $81.1 \%$ of students with average scale agree 6.23 if users are comfortable and satisfied with kopaja.id.

From the results of testing the Perceived Usability Website by 55 users as respondents, the interaction dimension received the lowest assessment (average score of 5.52) compared to the dimensions of navigation, speed, and behaviour. The kopaja.id page does not yet have a menu for direct interaction with users such as realtime chat boxes so that users can respond to specific needs.

\section{CONCLUSION}

Kopaja.id development on the topic of general tax provisions has thirteen materials that can meet the learning achievements of special knowledge for DIV Public Sector Accounting students following the national standards of Indonesian vocational education. Besides, the test results of the panel and interface systems show that the system is proper and functioning correctly. From the user side, the perceived assessment when using the Kopaja.id page as online tax learning provides comfort in studying taxes and has access speed, easy navigation. However, in terms of interaction from users to learning pages, it is not optimal. Meanwhile, the results of independent measurement for technology readiness have reached TRL 6.

The development of online learning media is suitable for use in the public as a learning medium. Users give recommendations such as, provide simulation material for making tax-payer identity number or NPWP which stands for Nomor Pokok Wajib Pajak, filling tax report as material for particular skills, discussion menu, and provide video materials for visual learners. Subsequent development research can meet user needs in the interaction dimension.

\section{ACKNOWLEDGMENTS}

The authors would like to thank the UGM Vocational College, for funding this research so that Kopaja.id can be developed in a more systematic, measurable, and useful way for the dissemination of tax science to students online via the internet. This learning material can also be accessed and used by SMA/SMK/MA students who are interested in studying tax online. Our gratitude also goes to Azza and Amal who have helped develop the kopaja.id website system version 2, Dira and Titis as the originators of Kopaja.id who have played a role in opening discourse, Dipta, Jauza, Dirga, Emel, and Gery who have helped in Kopaja.id development.

\section{REFERENCES}

Aghni, R. I. (2020). Spada-Indonesia PPG dalam jabatan. In Modul 6: Administrasi pajak. Kementerian Riset, Teknologi, dan Pendidikan Tinggi. http://ppg.spada.ristekdikti.go.id/ master/course/view.php?id=1128

Bawden, D. (2001). Information and digital literacies: A review of concepts. Journal of Documentation, 57(2), 218-259. https://doi.org/10.1108/EUM0000000007083

Bloom, B. S., Engelhart, M. D., Furst, E. J., Hill, W. H., \& Krathwohl, D. R. (1956). Taxonomy of educational objectives, Handbook I: Cognitive domain. David McKay Co. 
Cox, J. (2019). 10 Ways to make learning fun for students. ThoughtCo.Com. Retrieved from https://www.thoughtco.com/how-to-make-learning-fun-2081740

Dick, W., Carey, L., \& Carey, J. O. (2005). The systematic design of instruction. Pearson/Allyn and Bacon.

Dick, W., Carey, L., \& Carey, J. O. (2009). The systematic design of instruction. Pearson/Allyn and Bacon.

Direktorat Jenderal Pembelajaran dan Kemahasiswaan Kementerian Riset, Teknologi, dan Pendidikan Tinggi. (2019). Inklusi kesadaran pajak melalui Spada Indonesia. Retrieved from https://belmawa.ristekdikti.go.id/inklusi-kesadaran-pajak-melalui-spada-indonesia/

D’Angelo, T., Bunch, J. C., \& Thoron, A. (2018). Instructional design using the Dick and Carey systems approach. The Institute of Food and Agricultural Sciences (IFAS) Extension.

Gilster, P. (1997). Digital literacy. Wiley Computer.

Ikatan Akuntan Indonesia Kompartemen Akuntan Pendidik. (2015). Standar nasional pendidikan untuk pendidikan vokasi akuntansi. Working Paper.

Kamus Besar Bahasa Indonesia. (2016). KBBI daring. Badan Pengembangan Bahasa dan Perbukuan, Kementerian Pendidikan dan Kebudayaan Republik Indonesia. Retrieved from https://kbbi.kemdikbud.go.id

Kuntarto, E. (2017). Keefektifan model pembelajaran daring dalam perkuliahan Bahasa Indonesia di perguruan tinggi. Journal Indonesia Language Education and Literature, 3(1), 99-110. Retrieved from https://www.syekhnurjati.ac.id/jurnal/index.php/jeill/article/view/1820

Law of the Republic of Indonesia No. 28 of 2007 concerning General Provision and Taxation Procedure. (2007).

Law of the Republic of Indonesia No. 16 of 2009 concerning the Stipulation of Government Regulation in Lieu of Law Number 5 of 2008 regarding the Fourth Amandment to Law Number 6 of 1983 regarding General Provision and Taxation Procedure tentang Ketentuan Umum dan Tata Cara Perpajakan into Law. (2009).

Sugiyono, S. (2015). Metode penelitian kuantitatif, kualitatif, dan $R \& D$. Alfabeta.

Sudjana, N. (2017). Penilaian hasil proses belajar mengajar (20th ed.). Remaja Rosdakarya.

Thorne, K. (2003). Blended learning: How to integrate online \& traditional learning. Kogan Page.

Wang, J., \& Senecal, S. (2007). Measuring perceived website usability. Journal of Internet Commerce, 6(4), 97-112. https://doi.org/10.1080/15332860802086318 